\title{
Role of Platelet-activating Factor in Chinese Hamster Ovary Cell Responses to Cholera Toxin
}

\author{
Nathan M. Thielman, ${ }^{\star \ddagger}$ M. Marcinkiewicz, ${ }^{\S}$ J. Sarosiek, ${ }^{\S}$ Guodong D. Fang, ${ }^{\star}$ and Richard L. Guerrant ${ }^{\star \ddagger}$ \\ *Division of Geographic and International Medicine, ${ }^{\ddagger}$ Division of Infectious Diseases, and ${ }^{\S}$ Division of Gastroenterology, Department of \\ Medicine, University of Virginia School of Medicine, Charlottesville, Virginia 22908
}

\begin{abstract}
Cholera toxin (CT)-induced intestinal secretion and Chinese hamster ovary cell (CHO) elongation involves cyclic adenosine monophosphate and protein synthesis-dependent prostaglandin formation. We previously reported inhibition of CT-induced intestinal secretion and CHO elongation by platelet-activating factor (PAF) receptor antagonists and secretion of PAF by human intestinal epithelial cells exposed to CT. Herein, we show that PAF is involved after cAMP and that PAF, like CT, mediates prostaglandin $\mathrm{E}_{2}$ synthesis in CHO cells. CT-induced CHO elongation was blocked by specific PAF receptor antagonists, BN52021 and SR27417. SR27417 blocked dibutyryl cAMP-induced CHO elongation, but did not alter CHO elongation caused by $\mathrm{PGE}_{2}$. Neither CT-stimulated cAMP accumulation nor $\mathrm{PGE}_{2}$ production was inhibited by $\mathrm{SR} 27417$. Both $\mathrm{PGE}_{2}$ and PAF caused significant $\mathrm{CHO}$ elongation, but the latter did not stimulate significant cAMP production. In addition, PAF, like $\mathrm{CT}$ and dibutyryl cAMP, stimulated significant $\mathrm{PGE}_{2}$ production. Finally, the protein synthesis inhibitor cycloheximide, which completely blocks the effect of CT on prostaglandin synthesis, also blocked that of PAF, suggesting that PAF also mediates protein synthesis-dependent prostaglandin formation. We conclude that PAF is involved in $\mathrm{CHO}$ cytoskeletal responses to $\mathrm{CT}$ after the accumulation of $\mathrm{CAMP}$ and, like CT, PAF stimulates protein synthesis-dependent prostaglandin accumulation. (J. Clin. Invest. 1997. 99:19992004.) Key words: platelet-activating factor - cyclic adenosine monophosphate - cholera toxin - prostaglandins $\bullet$ cytoskeleton
\end{abstract}

\section{Introduction}

Adenylate cyclase activation (1-4) and prostaglandin synthesis (5-8), widely believed to be of pathogenic significance in the secretory diarrhea caused by cholera toxin, correspond with characteristic morphologic changes observed in Chinese ham-

Address correspondence to Richard L. Guerrant, Division of Geographic and International Medicine, Box 485, University of Virginia School of Medicine, Charlottesville, VA 22908. Phone: 804-924-5242; FAX: 804-977-5323.

Received for publication 1 November 1995 and accepted in revised form 30 January 1997.

J. Clin. Invest.

(C) The American Society for Clinical Investigation, Inc.

0021-9738/97/04/1999/06 \$2.00

Volume 99, Number 8, April 1997, 1999-2004 ster ovary $(\mathrm{CHO})^{1}$ cells (9-11). Recent evidence suggests that cholera toxin (CT)-induced prostaglandin synthesis and cAMP formation in $\mathrm{CHO}$ cells are interrelated. Peterson and co-workers have shown that dibutyryl cAMP causes arachidonic acid release from $\mathrm{CHO}$ cells, and that this step involves synthesis of phospholipase $\mathrm{A}_{2}$ activating protein, which is ultimately responsible for prostaglandin production $(11,12)$.

We have shown that platelet-activating factor (PAF), a well documented secretagogue (13-17), and a potent stimulus for prostaglandin synthesis via phospholipase $\mathrm{A}_{2}(18,19)$ is a necessary cofactor for both secretion and $\mathrm{CHO}$ cell elongation caused by cholera toxin (20). Moreover, we observed PAF secretion both in mucosal homogenates of rabbit ileal loops and in human intestinal epithelial cells (T84 cell line) exposed to cholera toxin. The relevance of these findings, however, to classical mechanisms of cholera toxin-mediated effects on cells has not been determined. Herein, using highly selective PAF receptor antagonists, we explore the relationship of PAF to CT-mediated $\mathrm{CHO}$ cell elongation, in particular as it relates to the sequence of cAMP production and prostaglandin effects.

\section{Methods}

Morphologic and viability studies. Stock cultures of CHO-K1 cells (CCL61; American Type Culture Collection, Rockville, MD) were grown in $\mathrm{F} 12$ medium supplemented with $10 \% \mathrm{FCS}$ in $5 \% \mathrm{CO}_{2}$ at $37^{\circ} \mathrm{C}$ and were passaged by trypsinization. For morphologic studies, freshly trypsinized cells in $200 \mu$ l of F12 medium with 1\% FCS were added to each well of a 96-well plate and incubated overnight in 5\% $\mathrm{CO}_{2}$ at $37^{\circ} \mathrm{C}$ as previously described (8). Cholera toxin, with or without the PAF receptor antagonists BN52021 or SR27417, prostaglandin $E_{1}$, prostaglandin $E_{2}$, or platelet activating factor were added to the designated wells, which were again incubated overnight. Cells were fixed with $100 \%$ methanol, stained with Giemsa, and the percentage of cells elongated in each well was counted. Cells were considered elongated when they were clearly bipolar, elongated three times or more their width, and had lost their knoblike projections. For each well, 100 cells were counted. To assess the effect of PAF antagonists on $\mathrm{CHO}$ cell viability at $24 \mathrm{~h}$, additional wells containing $10^{-5}$ to $10^{-7} \mathrm{M}$ SR27417, were examined for trypan blue exclusion, and the percentage of cells taking up trypan blue was counted. In addition, lactate dehydrogenase was measured in supernatants of cells exposed to $10^{-5}$ to $10^{-7}$ SR27417 using a lactate dehydrogenase quantitative colorimetric determination kit.

Cyclic AMP determinations. CHO cells were grown to near confluence in $60-\mathrm{mm}$ tissue culture dishes and incubated for times ranging from $2 \mathrm{~min}$ to $24 \mathrm{~h}$ in F12 medium with $1 \%$ FCS with $10 \mathrm{ng} / \mathrm{ml}$ of cholera toxin (with or without $10^{-6} \mathrm{M}$ SR27417), $10^{-5} \mathrm{M}$ prostaglandin $\mathrm{E}_{2}$, or $10^{-5} \mathrm{M}$ PAF. Incubations were terminated by aspiration of the medium and addition of $1 \mathrm{ml} 0.1 \mathrm{~N} \mathrm{HCl}$ to each plate,

1. Abbreviations used in this paper: $\mathrm{CHO}$, Chinese hamster ovary; $\mathrm{CT}$, cholera toxin; $\mathrm{PAF}$, platelet-activating factor; $\mathrm{PLA}_{2}$, phospholipase $\mathrm{A}_{2}$. 
which remained at room temperature for $30 \mathrm{~min}$. Supernatants were assayed for cAMP using a radioimmunoassay by methods previously described (21). Cellular protein was dissolved in $0.2 \mathrm{~N} \mathrm{NaOH}$ and determined by the method of Lowry et al. (22). cAMP concentrations are expressed as picomoles of cAMP per milligram of cellular protein.

$P G E_{2}$ measurements. CHO cells grown to near confluence in 60$\mathrm{mm}$ tissue culture dishes in F12 with $1 \%$ FCS were exposed to CT, dibutyryl cAMP, or PAF. In protein synthesis inhibition experiments, cells were preincubated for 30 min with cycloheximide or actinomycin $\mathrm{D}$, each at $10 \mu \mathrm{g} / \mathrm{ml}$. Incubations were terminated at $4 \mathrm{~h}$ and medium was aspirated promptly into 1:4 water:ethanol with glacial acetic acid and citrate aspirin. $\mathrm{PGE}_{2}$ was eluted over an Amprep minicolumn (C18; Amersham Corp., Arlington Heights, IL) with ethyl acetate. The eluate, after evaporating to dryness under nitrogen and reconstituting in phosphate buffered gelatin saline, underwent methyl oximation overnight. $\mathrm{PGE}_{2}$ content was then quantified with a radioimmunoassay. Cellular protein for each experiment was determined by Lowry assay.

Materials. F12 medium was supplied by Gibco Laboratories (Grand Island, NY). Fetal calf serum, prostaglandin $\mathrm{E}_{2}$, cycloheximide, and actinomycin D were obtained from Sigma Chemical Co. (St. Louis, MO). Cholera toxin (\#55135) was obtained from ICN Biomedical Inc. (Aurora, $\mathrm{OH}$ ) and from List Biological Laboratories, Inc. (Campbell, CA) (\#CVX-466). PAF was supplied by Calbiochem Corp. (La Jolla, CA). BN52021 and SR27417 were the kind gifts of Drs. Pierre Braquet and J.M. Herbert from Institut Beaufour (Paris, France) and Sanofi Recherche (Toulouse Cedex, France). Prostaglandin $\mathrm{E}_{2}$ radioimmunnoassay kit was purchased from Amersham Corp. Tissue cultureware was obtained from Beckton Dickinson \& Co. (Lincoln Park, NJ). The lactate dehydrogenase determination kit was obtained from Sigma Diagnostics (St. Louis, MO).

Statistics. Statistical analysis was by Student's $t$ test for analyses comparing less than three groups. One way analysis of variance procedures were used in analyses involving multiple comparisons with significant differences assessed conservatively with the Bonferroni test. Logistic regression modeling was used for comparing doseresponse curves with and without antagonist present.

\section{Results}

Effects of PAF antagonists on $\mathrm{CHO}$ cell elongation. In preliminary studies, we reproduced the dose-response $\mathrm{CHO}$ cell elongation to $\mathrm{CT}$ and demonstrated no change in baseline morphology of unstimulated CHO cells exposed to the BN52021 and SR27417 at concentrations $\leq 10^{-6} \mathrm{M}$. Moreover, $10^{-6} \mathrm{M}$ SR27417 did not affect $\mathrm{CHO}$ cell viability, as measured by trypan blue uptake $(0.3 \pm 0.6 \%$ vs. $1 \pm 1 \%$ for PBS, $n=6$ total, $P>0.05)$ and lactate dehydrogenase $(\mathrm{LDH})$ release $(5.1 \pm 8.3$ LDH activity units vs. $54.4 \pm 94.8$ for PBS, $n=9$ total, $P>0.05$; Triton $X$ positive controls with $565.7 \pm 102.6, n=5$ ). Protein synthesis, as determined by ${ }^{35} \mathrm{~S}$-methionine-cysteine incorporation into trichloroacetic acid-precipitable proteins at $4 \mathrm{~h}$, while inhibited by cycloheximide in the doses used, was not inhibited by SR27417. In data pooled from two observers and four experiments shown in Fig. $1 \mathrm{~A}$, a significant inhibitory effect on $\mathrm{CHO}$ cell elongation was observed with SR27417 $(P<0.003)$ and BN52021 $(P<0.001)$ overall in logistic regression plots of log dose $\mathrm{CT}$ (nanograms per milliliter) versus percent $\mathrm{CHO}$ cell elongation. For PBS controls (not shown) run with each experiment, the mean percent $\mathrm{CHO}$ elongation was $4 \% \pm$ $2.9 \%, n=30$. As shown in Fig. $1 B$, membrane permeable, dibutyryl cAMP also effected dose-dependent $\mathrm{CHO}$ cell elongation, which was significantly blocked by the PAF receptor antagonists $(P<0.001$ overall for both SR27417 and BN52021 in logistic regression plots of log dose dibutyryl cAMP versus percent $\mathrm{CHO}$ cell elongation).

Effects of PAF, and prostaglandins $E_{1}$ and $E_{2}$ on $C H O$ cell elongation. In Fig. 2 are shown the effects of PAF and prostaglandin $\mathrm{E}_{1}$ and $\mathrm{E}_{2}$ on $\mathrm{CHO}$ cell elongation. Significant elongation $(P<0.001$, compared with PBS controls $)$, morphologically similar to that produced by both CT and dibutyryl cAMP, was observed at PAF and prostaglandin $\mathrm{E}_{2}$ concentrations of $10^{-7}$ to $10^{-5} \mathrm{M}$ and at prostaglandin $\mathrm{E}_{1}$ concentrations of $10^{-5}$
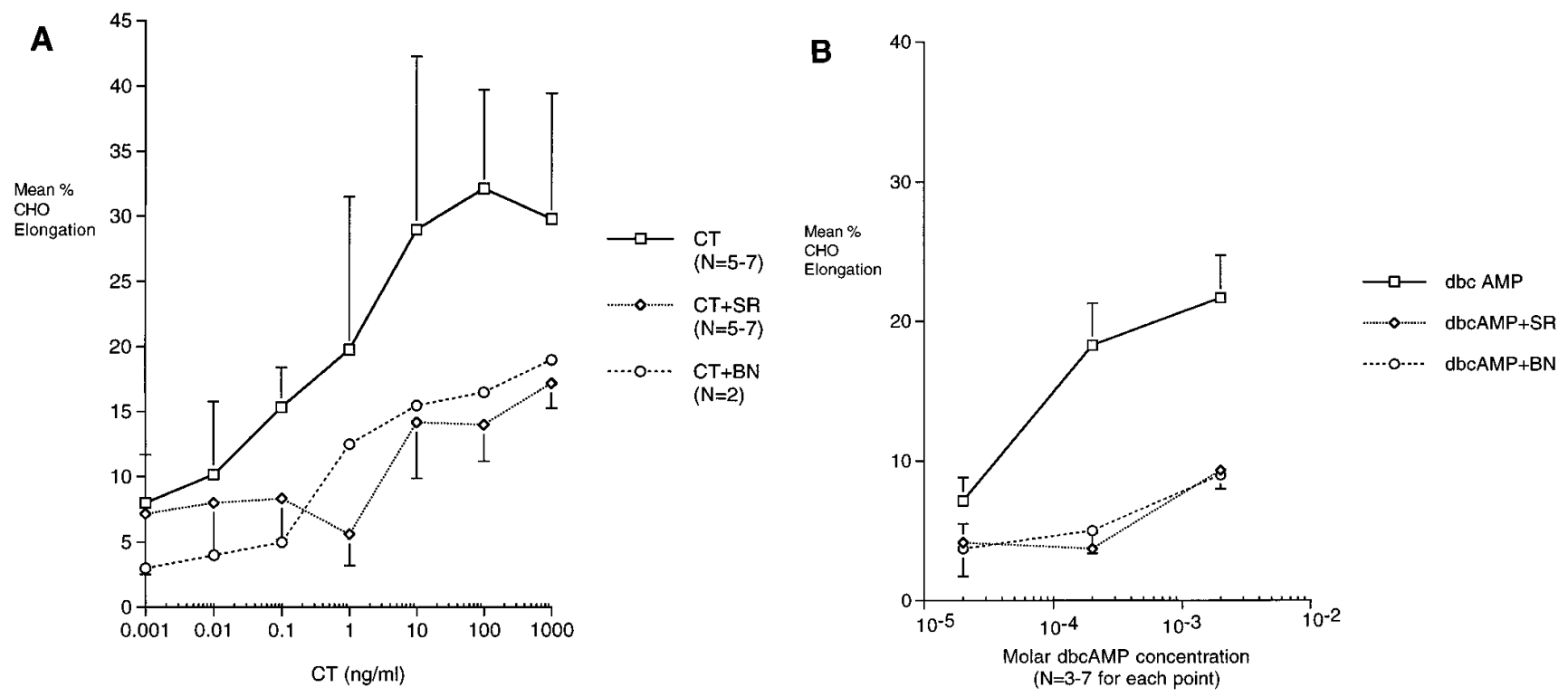

Figure 1. Effects of PAF receptor antagonists SR27417 and BN52021 on CHO cell elongation responses to cholera toxin $(A)$ and dibutyryl cAMP $(B)$. Bars represent 1 SD. SR27417 and BN52021 significantly inhibited CT effects on CHO cell elongation $(P<0.003$ and $P<0.001$ overall, respectively) as well as those of dibutyryl cAMP $(P<0.001$, each) in plots of log dose CT (nanograms per milliliter) or dibutyryl molar concentration versus percentage $\mathrm{CHO}$ cell elongation. 


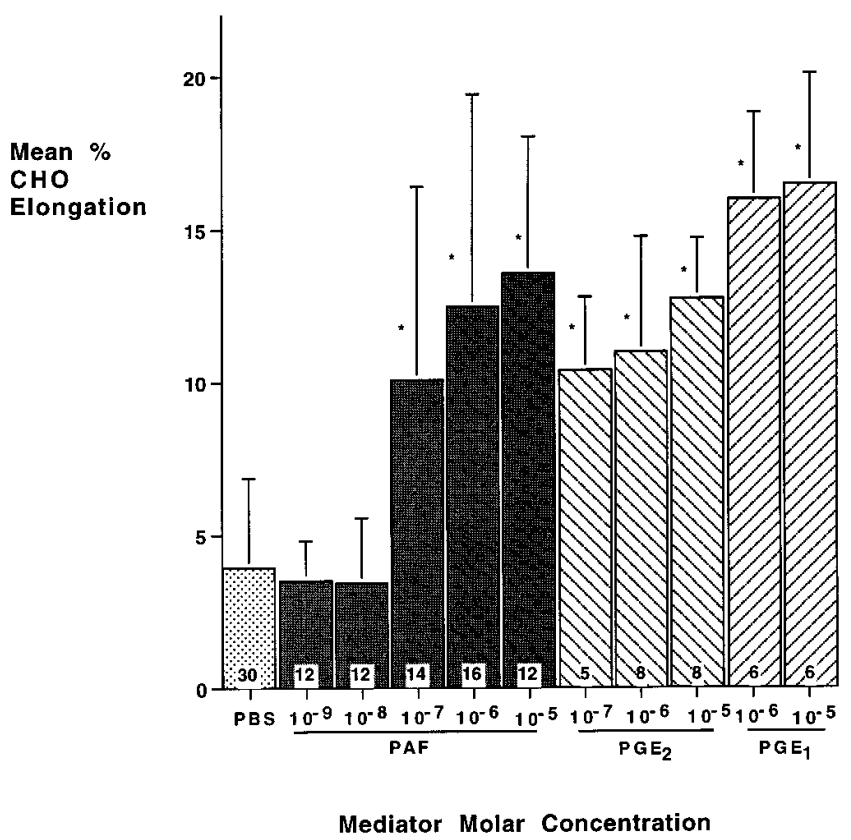

Figure 2. $\mathrm{CHO}$ cell elongation induced by $\mathrm{PAF}$ and prostaglandin $\mathrm{E}_{1}$ and $\mathrm{E}_{2} . n$ for each datum is at bottom of column; bars represent $1 \mathrm{SD}$; $* P<0.001$ compared with PBS control, significant by Bonferroni test where $\alpha=0.05$ corresponds with $P<0.005$ for comparisons of the 10 experimental groups vs. controls.

and $10^{-6} \mathrm{M}$. The $\mathrm{CHO}$ cell elongation caused by $\mathrm{PGE}_{2}$ at $10^{-9}$ to $10^{-5} \mathrm{M}(5-21 \%)$ was not altered by the presence of $10^{-6} \mathrm{M}$ SR27417.

Effects of PAF antagonists, $P A F$, and prostaglandin $E_{2}$ on cAMP accumulation. Shown in Fig. 3 are cAMP measurements from $\mathrm{CHO}$ cells exposed for varying time intervals to doses of CT $(10 \mathrm{ng} / \mathrm{ml})$, PAF $\left(10^{-5} \mathrm{M}\right)$, and prostaglandin $\mathrm{E}_{2}$ $\left(10^{-5} \mathrm{M}\right)$, all at concentrations that caused significant $\mathrm{CHO}$ cell elongation. The increase in cAMP after exposure to $\mathrm{CT}$ in the presence of SR27417 was similar to that observed in $\mathrm{CHO}$ cells exposed to CT alone $(P>0.2)$. Concentrations of PAF and prostaglandin $\mathrm{E}_{2}$ that maximally stimulated $\mathrm{CHO}$ cell elongation did not alter cAMP levels significantly from controls at $24 \mathrm{~h}$. A transient and slight increase in cAMP formation that was statistically significant $(P<0.001$ with Bonferroni $\alpha=0.05$ significance corresponding to $P<0.0026$ for multiple comparisons) was noted after 4-min exposure to prostaglandin $\mathrm{E}_{2}$; no increase was seen after PAF exposure. At 2-4 h after exposure, both $\mathrm{PAF}$ and prostaglandin $\mathrm{E}_{2}$ exposure effected significant $(P<0.001)$ decreases in cAMP accumulation.

Effects of $C T$, dibutyryl cAMP, and PAF on prostaglandin $E_{2}$ production. As noted in Table I, a graded increase in $\mathrm{PGE}_{2}$ production was measured after a $4-\mathrm{h}$ incubation with $0.1 \mathrm{ng} / \mathrm{ml}$ CT $(25 \pm 21 \%, n=4$, significant by Bonferroni test where $\alpha=$ 0.05 significance corresponds to $P<0.008$ for multiple comparisons), $1 \mathrm{ng} / \mathrm{ml} \mathrm{CT}(36 \pm 75 \%, n=4), 10 \mathrm{ng} / \mathrm{ml} \mathrm{CT}(62 \pm 25 \%$, $n=5, P<0.008)$, and $50 \mathrm{ng} / \mathrm{ml} \mathrm{CT}(79 \pm 13 \%, n=2) .10^{-3} \mathrm{M}$ dibutyryl cAMP also caused significant $\mathrm{PGE}_{2}$ accumulation compared with controls $(78 \% \pm 47 \%$ increase, $n=4, P<$ 0.008). PAF stimulated $\mathrm{PGE}_{2}$ production from $\mathrm{CHO}$ cells at $10^{-6} \mathrm{M}(20 \pm 26 \%$ increase, $n=5)$ and $10^{-5} \mathrm{M}(47 \pm 37 \%$ in-
Table I. Prostaglandin Production Stimulated by Cholera Toxin, Dibutyryl cAMP, and $P A F$

\begin{tabular}{lccc}
\hline \multicolumn{1}{c}{ Condition } & $\begin{array}{c}\text { Percent increase } \\
\text { over controls }\end{array}$ & $n$ & Significance \\
\hline & & & $P<$ \\
Cholera toxin $(\mathrm{ng} / \mathrm{ml})$ & & & \\
0.1 & $25 \pm 21$ & 4 & $0.008^{*}$ \\
1 & $36 \pm 75$ & 4 & $\mathrm{NS}$ \\
10 & $62 \pm 25$ & 6 & $0.008^{*}$ \\
50 & $79 \pm 13$ & 2 & - \\
$10+$ cycloheximide & $-30 \pm 32$ & 3 & $0.002^{\ddagger}$ \\
$10+$ actinomycin D & $-45 \pm 28$ & 2 & - \\
Dibutyryl cAMP (molar concentration) & & & \\
$5 \times 10^{-4}$ & $-18 \pm 21$ & 2 & - \\
$10^{-3}$ & $78 \pm 47$ & 4 & $0.008^{*}$ \\
PAF (molar concentration) & & & \\
$10^{-6}$ & $20 \pm 26$ & 5 & $\mathrm{NS}^{*}$ \\
$10^{-5}$ & $47 \pm 37$ & 12 & $0.008^{*}$ \\
$10^{-5}+$ cycloheximide & $-25 \pm 25$ & 5 & $0.001^{\S}$ \\
$10^{-5}+$ actinomycin D & $-10 \pm 8$ & 2 & - \\
& & & \\
\hline
\end{tabular}

Each value is the mean percentage increase over experimental controls \pm standard deviation. *Analysis of variance was done for groups compared with controls; $P<0.008$ achieves statistical significance by Bonferroni test (corresponding to $\alpha=0.05$ for comparison of the six experimental groups with $n>2$ ) versus controls; "significant by Student's $t$ test versus CT $10 \mathrm{ng} / \mathrm{ml}$; ${ }^{\circledR}$ significant by Student's $t$ test versus PAF $10^{-5} \mathrm{M}$. Data shown span four experiments.

crease, $n=12)$, the latter being statistically significant $(P<$ 0.008). SR27417 at $10^{-6} \mathrm{M}$ added $30 \mathrm{~min}$ before the addition of CT did not block the effects of CT on $\mathrm{PGE}_{2}$ synthesis $(335 \mathrm{pg} /$ $\mathrm{mg} \mathrm{CHO}$ with CT $10 \mathrm{ng} / \mathrm{ml}, n=3$ vs. $439 \mathrm{pg} / \mathrm{mg}$ CHO with CT $10 \mathrm{ng} / \mathrm{ml}$ with SR27417, $n=3$ ).

Effects of protein synthesis inhibitors on CT- and PAFmediated prostaglandin $E_{2}$ production. Summarized in Table I along with other prostaglandin production experiments are the effects of cycloheximide and actinomycin D on prostaglandin $\mathrm{E}_{2}$ production. Cycloheximide, an inhibitor of translation, and actinomycin, an inhibitor of transcription, completely blocked PAF- and CT-mediated prostaglandin $\mathrm{E}_{2}$ production. In addition, constitutive prostaglandin synthesis was decreased by exposure to these agents.

\section{Discussion}

Since its description by Guerrant et al. (9), the morphologic changes of CT-stimulated $\mathrm{CHO}$ cells have been widely used as a means to detect the presence of cholera and cholera-like enterotoxins in stool (23-27) and have proven a useful tool to probe cholera toxin mechanisms of action on eukaryotic cells $(12,28)$. In the present report, we have used these cytoskeletal responses, as well as prostaglandin and cAMP production of $\mathrm{CHO}$ cells to define more precisely the sequence of molecular events in cellular responses to CT.

As previously reported, the inhibition of CT-induced secretion in ligated rabbit ileal loops by selective PAF antagonists and of CT-induced $\mathrm{CHO}$ cell elongation, as well as detection of PAF in the supernatants of human epithelial cells exposed 


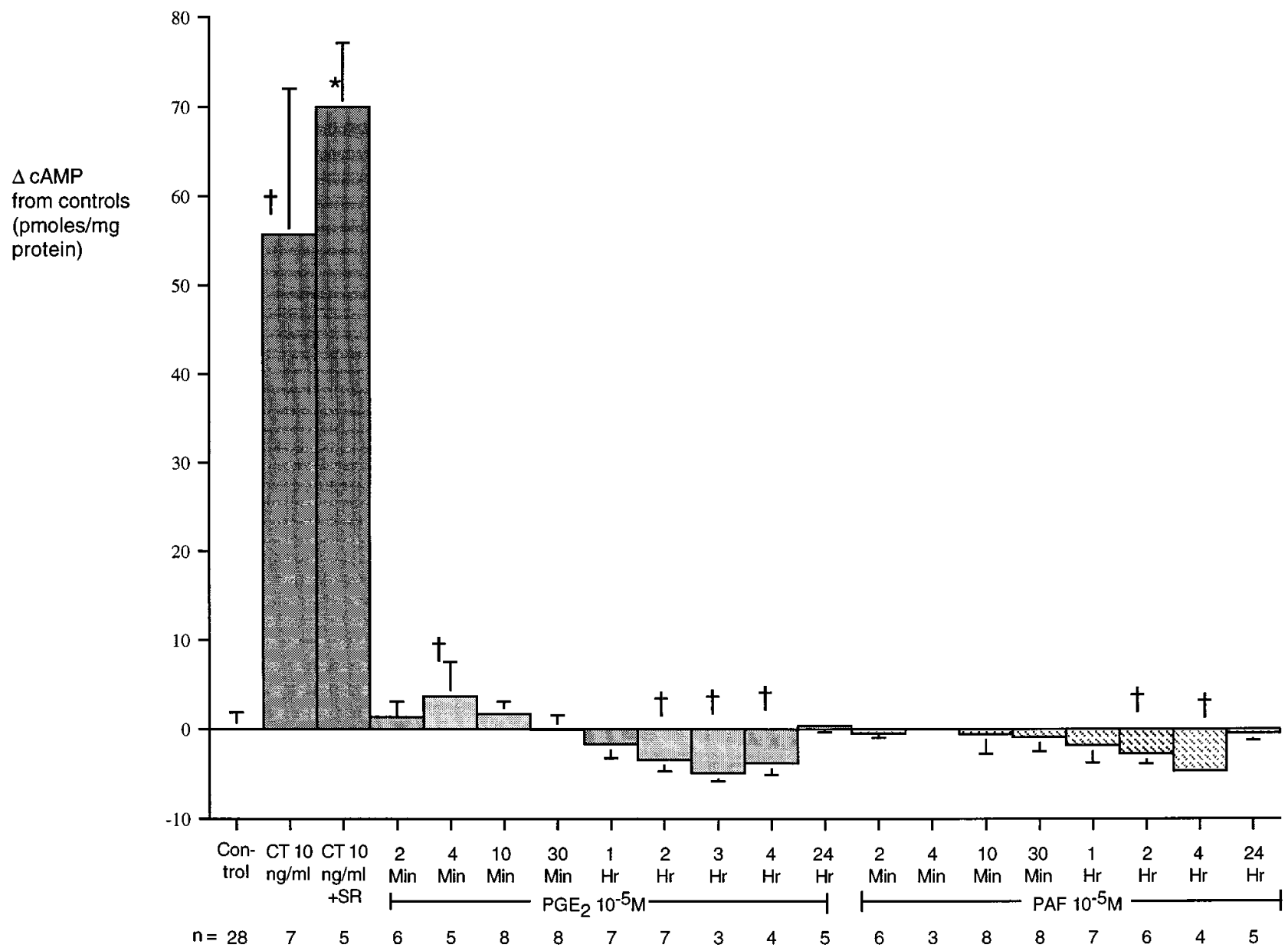

Figure 3. Cyclic AMP production by $\mathrm{CHO}$ cells exposed to $\mathrm{CT}$, prostaglandin $\mathrm{E}_{2}$, and PAF. ${ }^{\dagger}$ Statistically significantly different from controls by Bonferroni test $(P<0.0026) ;{ }^{*} P>0.05$ by Student's $t$ test vs. CT $10 \mathrm{ng} / \mathrm{ml}$ without SR27417. Data are pooled from six experiments; bars represent 1 SD.

to $\mathrm{CT}$, all suggest that PAF is involved in biological responses to CT (20). Although impressive, the lack of complete inhibition by the antagonists offers the possibility that other mechanisms, in addition to PAF effects, may also be involved. In this study, several different experiments demonstrate that PAF is involved after the formation of cAMP. First, the PAF receptor antagonists blocked dibutyryl cAMP-mediated $\mathrm{CHO}$ cell elongation, just as they did with cholera toxin. Second, CT-induced cAMP production in $\mathrm{CHO}$ cells was completely unaffected by PAF receptor antagonists. Third, although a transient early increase in cAMP was noted in response to prostaglandin $E_{2}$, $\mathrm{PAF}$ (at doses that maximally stimulated $\mathrm{CHO}$ cell elongation) did not cause significant cAMP accumulation. Hence, cAMP accumulation appears to be a proximal event in $\mathrm{CHO}$ cell responses to $\mathrm{CT}$, rendering $\mathrm{PAF}$ and $\mathrm{PGE}_{2}$ likely candidates for mediating cAMP effects of CT on cells.

In experiments predating the discovery of the central role of cAMP, cholera toxin-induced intestinal fluid accumulation was shown to be inhibited by cycloheximide, suggesting a protein synthesis dependence $(29,30)$. Since then, the pivotal role for prostaglandins in the mechanism of action of CT was suggested by studies demonstrating: $(a)$ increases in prostaglandins in intestinal mucosa in animal models $(8,31)$ as well as
CHO cells (32), (b) increased PGs in jejunal aspirates from patients with cholera (33), and (c) animal model studies demonstrating decreased CT-induced secretion with cyclooxygenase inhibitors $(5,6)$. Like CT, dibutryl cAMP stimulates prostaglandin $\mathrm{E}_{2}$ release (32); moreover, the arachidonic acid release caused by both CT and dibutryl cAMP is blocked by cycloheximide and actinomycin $\mathrm{D}$ (12). Although prostaglandin $\mathrm{E}_{2}$ is considered to represent a "classic" receptor-mediated cAMP stimulus, cAMP levels in animal models are not influenced by indomethacin despite inhibition of CT-mediated secretion (34, 35 ), and the PG doses required to stimulate cAMP generation in vitro are two to three logs greater than those needed to stimulate intestinal secretion (36). The present data, taken in the context of these earlier observations, suggest that CT-stimulated cAMP accumulation mediates protein synthesis-dependent prostaglandin production both directly and indirectly, via a pathway involving PAF.

Among the diverse biological activities of cAMP, recent evidence suggests that, in some cell types, this nucleotide is capable of stimulating phospholipase $A_{2}$ (37-39), a key enzyme involved in the synthesis of both PAF and prostaglandins (18, 37). In CHO cells, cAMP has been found to promote transcription of mRNA encoding phospholipase or a phospholi- 
pase-activating protein, thereby leading to prostaglandin synthesis (11), and Peterson et al. has recently described CT induction of phospholipase $\mathrm{A}_{2}$-activating protein synthesis in another mammalian cell line (12). The critical role of PAF in this pathway is demonstrated by the findings we report here. Our observations that PAF antagonists block elongation effects of CT and cAMP but not that of prostaglandins suggest that PAF may be involved before prostaglandin synthesis. This is supported by the additional experiments demonstrating that PAF, like CT and dibutyryl cAMP, directly stimulates prostaglandin $\mathrm{E}_{2}$ production. That this $\mathrm{PAF}$-mediated prostaglandin production, like that of $\mathrm{CT}$, is protein synthesis dependent further strengthens our suggestion that PAF induces a protein synthesis-dependent activation of PG synthesis, presumably via phospholipase $\mathrm{A}_{2}\left(\mathrm{PLA}_{2}\right)$ or a $\mathrm{PLA}_{2}$-activating protein. PAF-induced synthesis of prostaglandins via $\mathrm{PLA}_{2}$ activation has been well described in human polymorphonuclear leukocytes (38), rat Kupffer cells (19), rat liver cells (39), and other cell lines (18). Since the SR27417 did not block CT-induced PG synthesis, a direct effect of CT on PG formation (probably via $\mathrm{PLA}_{2}$ ) also seems likely.

In addition, PAF production may further augment cAMP activation of $\mathrm{PLA}_{2}$, or a cAMP-independent effect of CT on $\mathrm{PAF}$ and $\mathrm{PLA}_{2}$ may occur. Interestingly, such an effect of CT on PAF has been suggested by Gandhi et al., who found that in rat Kupffer cells CT synergistically stimulated PAF-induced glycerophosphoinositol release and prostaglandin synthesis, without apparent cAMP involvement (19). We have successfully measured PAF from human intestinal epithelial cells and homogenates of rabbit ileal mucosa exposed to cholera toxin (20). However, attempts to measure PAF from CT-stimulated $\mathrm{CHO}$ cells have not been successful. Limited data (not shown) in our laboratory suggest that PAF may be rapidly bound or degraded in this system, making direct measurements of PAF accumulation difficult.

In summary, the present data suggest that CT effects on $\mathrm{CHO}$ cells involve PAF-dependent pathways after adenylate cyclase activation and cAMP formation and that PAF, like CT, stimulates synthesis-dependent prostaglandin formation. These findings may explain the previously reported effects of CT and cAMP on prostaglandin synthesis. An understanding of these molecular events in the action of cholera toxin on eukaryotic cells may lead to improved understanding of cholera toxin effects on cytoskeleton and intestinal secretion and potentially to new approaches to antisecretory therapy.

\section{Acknowledgments}

We thank Mrs. Yatta Jacob and Mrs. Mary Loving for assistance with preparing the manuscript.

This work was supported in part by National Institutes of Health training grant T32AI07046 and by the Rockefeller Foundation.

\section{References}

1. Kimberg, D.V., M. Field, J. Johnson, A. Henderson, and E. Gershon. 1971. Stimulation of intestinal mucosal adenyl cyclase by cholera enterotoxin and prostaglandins. J. Clin. Invest. 50:1218-1230.

2. Guerrant, R.L., L.C. Chen, and G. Sharp. 1972. Intestinal adenyl-cyclase activity in canine cholera: correlation with fluid accumulation. J. Infect. Dis. 125:377-381

3. Chen, L.C., J.E. Rohde, and G. Sharp. 1971. Intestinal adenyl-cyclase activity in human cholera. Lancet. i:939-941.

4. Gill, D.M., and R. Meren. 1978. ADP-ribosylation of membrane proteins catalyzed by cholera toxin: basis of the activation of adenylate cyclase. Proc. Natl. Acad. Sci. USA. 75:3050-3054.

5. Gots, R.E., S.B. Formal, and R.A. Giannella. 1974. Indomethacin inhibition of Salmonella typhimurium, Shigella flexneri, and cholera-mediated rabbit ileal secretion. J. Infect. Dis. 130:280-284.

6. Jacoby, H.I., and C.H. Marshall. 1972. Antagonism of cholera enterotoxin by anti-inflammatory agents in the rat. Nature (Lond.). 235:163-165.

7. Pierce, N.F., C. Carpenter, Jr., H.L. Elliott, and W. Greenough III. 1971. Effects of prostaglandins, theophylline, and cholera exotoxin upon transmucosal water and electrolyte movement in the canine jejunum. Gastroenterology. 60:22-32.

8. Peterson, J.W., and G. Ochoa. 1989. Role of prostaglandins and cAMP in the secretory effects of cholera toxin. Science (Wash. DC). 245:857-859.

9. Guerrant, R.L., L.L. Brunton, R.C. Schnaitman, L.I. Rebhun, and A. Gilman. 1974. Cyclic adenosine monophosphate and alteration of Chinese hamster ovary cell morphology: a rapid, sensitive in vitro assay for the entertoxins of Vibrio cholerae and Escherichia coli. Infect. Immun. 10:320-327.

10. Hsie, A.W., C. Jones, and T.T. Puck. 1971. Further changes in differentiation state accompanying the conversion of Chinese hamster cells of fibroblastic form by dibutyryl adenosine cyclic $3^{\prime}: 5^{\prime}$-monophosphate and hormones. Proc. Natl. Acad. Sci. USA. 68:1648-1652.

11. Peterson, J.W., J.C. Reitmeyer, C.A. Jackson, and G.A.S. Ansare. 1991. Protein synthesis is required for cholera toxin-induced stimulation or arachidonic acid metabolism. Biochim. Biophys. Acta. 1092:79-84.

12. Peterson, J.W., S.S. Saini, W.D. Dickey, G.R. Klimpel, J.S. Bomalaski, M.A. Clark, X.J. Xu, and A.K. Chopra. 1996. Cholera toxin induces synthesis of phospholipase $\mathrm{A}_{2}$-activating protein. Infect. Immun. 64:2137-2143.

13. Hanglow, A.C., J. Bienenstock, and M.H. Perdue. 1989. Effects of platelet-activating factor on ion transport in isolated rat jejunum. Am. J. Physiol. 257:G845-G850.

14. Buckley, T.L., and J.R. Hoult. 1989. Platelet activating factor is a potent colonic secretagogue with actions independent of specific PAF receptors. Eur. J. Pharmacol. 163:275-283.

15. Bern, M.J., C.W. Sturbaum, S.S. Karayalcin, H.M. Berschneider, J.T. Wachsman, and D.W. Powell. 1989. Immune system control of rat and rabbit colonic electrolyte transport. Role of prostaglandins and enteric nervous system. J. Clin. Invest. 83:1810-1820.

16. MacNaughton, W.K., and D.G. Gall. 1991. Mechanisms of platelet-activating factor-induced electrolyte transport in the rat jejunum. Eur. J. Pharmacol. 200:17-23.

17. Berschneider, H.M., and D.W. Powell. 1992. Fibroblasts modulate intestinal secretory responses to inflammatory mediators. J. Clin. Invest. 89:484-489.

18. Shukla, S.D., A.W. Thurston, C.Y. Zhu, and A. Dhar. 1993. Platelet activating factor receptor functions via phosphoinositide turnover and tyrosine kinase. In Platelet Activating Factor Receptor: Signal Mechanisms and Molecular Biology. S.D. Shukla, editor. CRC Press. Boca Raton, FL. 41-59.

19. Gandhi, C.R., M.S. DeBuysere, and M.S. Olson. 1992. Platelet-activating factor-mediated synthesis of prostaglandins in rat Kupffer cells. Biochim. Biophys. Acta. 1136:68-74.

20. Guerrant, R.L., G.D. Fang, N.M. Thielman, and M.C. Fonteles. 1994. Role of platelet activating factor (PAF) in the intestinal epithelial secretory and Chinese hamster ovary $(\mathrm{CHO})$ cell cytoskeletal responses to choleratoxin. Proc. Natl. Acad. Sci. USA. 91:9655-9658.

21. Brooker, G., W.L. Terasaki, and M.G. Price. 1976. Gammaflow: a completely automated radioimmunoassay system. Science (Wash. DC). 194:270-276.

22. Lowry, O.H., N.J. Rosebrough, A.L. Farr, and R.J. Randall. 1951. Protein measurement with the Folin Phenol Reagent. J. Biol. Chem. 193:265-275.

23. Guerrant, R.L., R.A. Moore, P.M. Kirschenfeld, and M.A. Sande. 1975. Role of toxigenic and invasive bacteria in acute diarrhea of childhood. N. Engl. J. Med. 293:567-572.

24. Jiwa, S.F. 1981. Probing for enterotoxigenicity among the salmonellae: an evaluation of biological assays. J. Clin. Microbiol. 14:463-472.

25. Collins, S., E. O'Loughlin, J. O'Rourke, Z. Li, A. Lee, and M. Howden. 1992. A cytotonic, cholera toxin-like protein produced by Campylobacter jejuni. Comp. Biochem. Physiol. B Comp. Biochem. 103:299-303.

26. Turnbull, P.C., J.V. Lee, M.D. Miliotis, C.S. Still, M. Isaacson, and Q.S. Ahmad. 1985. In vitro and in vivo cholera toxin production by classical and El Tor isolates of Vibrio cholerae. J. Clin. Microbiol. 21:884-890.

27. Sack, D.A., J.C. McLaughlin, R.B. Sack, F. Orskov, and I. Orskov. 1977. Enterotoxigenic Escherichia coli isolated from patients at a hospital in Dacca. $J$. Infect. Dis. 135:275-280.

28. Guerrant, R.L., and L.L. Brunton. 1977. Characterization of the Chinese hamster ovary cell assay for the enterotoxins of Vibrio cholerae and Escherichia coli and for specific antisera, and toxoid. J. Infect. Dis. 135:720-728.

29. Serebro, H.A., F.L. Iber, J.H. Yardley, and T.R. Hendrix. 1969. Inhibition of cholera toxin action in the rabbit by cycloheximide. Gastroenterology. 56:506-511.

30. Grayer, D.T., H.A. Serebro, F.L. Iber, and T.R. Hendrix. 1970. Effect of cycloheximide on unidirectional sodium fluxes in the jejunum after cholera exotoxin exposure. Gastroenterology. 58:815-819.

31. Triadafilopoulos, G., C. Pothoulakis, R. Weiss, C. Giampaolo, and J.T. LaMont. 1989. Comparative study of Clostridium difficile toxin A and cholera 
toxin in rabbit ileum. Gastroenterology. 97:1186-1192.

32. Peterson, J.W., C.A. Jackson, and J.C. Reitmeyer. 1990. Synthesis of prostaglandins in cholera toxin-treated Chinese hamster ovary cells. Microb. Pathog. 9:345-353

33. Speelman, P., G.H. Rabbani, K. Bukhave, and J. Rask-Madsen. 1985. Increased jejunal prostaglandin E2 concentrations in patients with acute cholera. Gut. 26:188-193.

34. Kimberg, D., M. Field, E. Gershon, and A. Henderson. 1974. Effects of prostaglandins and cholera enterotoxin on intestinal mucosal cAMP accumulation: evidence against an essential role for prostaglandins in the action of toxin. J. Clin. Invest. 53:941-949.

35. Wald, A., G.S. Gotterer, G.R. Rajendra, N.A. Turjman, and T.R. Hen- drix. 1977. Effect of indomethacin on cholera-induced fluid movement, unidirectional sodium fluxes, and intestinal cAMP. Gastroenterology. 72:106-110.

36. Rask-Madsen, J., K. Bukhave, and E. Beubler. 1990. Influence of intestinal secretion of eicosanoids. J. Intern. Med. 228(Suppl. 1):137-144.

37. Chao, W., and M.S. Olson. 1993. Platelet-activating factor: receptors and signal transduction. Biochem. J. 292(Pt 3):617-629.

38. Nakashima, S., A. Suganuma, M. Sato, T. Tohmatsu, and Y. Nozawa. 1989. Mechanism of arachidonic acid liberation in platelet-activating factorstimulated human polymorphonuclear neutrophils. J. Immunol. 143:1295-1302.

39. Levine, L. 1988. Platelet-activating factor stimulates arachidonic acid metabolism in rat liver cells (C-9 cell line) by a receptor-mediated mechanism. Mol. Pharmacol. 34:793-799. 